\title{
Beyond Borders of Death and Time: Nietzsche's Theory of The Eternal Return of The Same in Ahmed Murad's Season of Gazelle Hunting, (Mussem Seed Elgezlan) ${ }^{(*)}$
}

\begin{abstract}
Man has always been preoccupied with all argumentative existential issues such as his mortal nature, the actuality of God's presence and the potential existence of a second life that hinders the attainment of a state of self-understanding that remains a perpetual void in all humans alike. Being concerned with such issues, the research draws heavily upon a philosophical approach that builds on Nietzsche's theory of the eternal return of the same. Nietzsche's hypothesis is that life is a succession of a repeated sequence that, once finished, is constantly repeated over and over with all pain and joy. This greatly destabilizes the border lines of the present, the past and the future. Subservient to Nietzsche's theory, are such abstract ideas of Theosophy as ethereal body, astral projection or incubation that help the individual to go through an out-of-self ethereal travel seeking knowledge and more insight in human nature. In light of this, the study seeks to emphasize the idea that knowledge is acquired through rational as well as irrational means like incubation or astral projection as a way of crossing borders of time and space. This idea is highlighted in Murad's Season of Gazelle Hunting (Mussem Seed Elgezlan) with a question in mind "which type of knowledge is gained as a result?" Thus, the study seeks to show the way such philosophical as well as theosophical theories and concepts are intricately weaved in Ahmed Murad's Season of Gazelle Hunting (Mussem Seed Elgezlan) for one purpose: highlighting man's lust for the attainment of self-knowledge and the disruption of the terror of his mortality, the most terrifying human dread. The paper poses and answers the question whether the
\end{abstract}

${ }^{(*)}$ Bulletin of the Faculty of Arts Volume 81 Issue 4 April 2021 
characters in Murad's novel manage to transcend their human limitation to gain knowledge through irrational means and, as a result, achieve a state of selfunderstanding. A further question is concerned with the way Murad's novel proposes a final perspective on the triangle of mortality, God's existence and selfknowledge.

Key words: Eternal recurrence-ethereal body- ethereal travel- astral projection-Theosophy-Nature- Medusa- Oedipus- God's existence- dreamsincubation-rational and irrational means of gaining knowledge.

الملخص العربى

ور اء حدود الموت و الوقت:نظرية التكر ارية لنيتشة فى رو ابة أحمد مر اد

$$
\text { "موسم صبد الغزلان" }
$$

انشغل الانسان على مر العصور بقضايا جدلية وجودية عديدة كالفناء ووجود اله ومدى مصداقية فكرة وجود حياة ما بعد الموت، كلها قضايا تحول بين فهم الذات القضية التى بقيت كثيرا ثخرة من ثخرات البشر وفجوة يصعب ملؤها. محاولة منه لتتاول هذه القضية الوجودية اعثد البحث: على نظرية فلسفية للفيلسوف نيتشه وهى نظرية العود الأبدى و التى تعنى أن كل ما يمر به الإنسان من سعادة و ألم ومعناة يتكرر بصورة مستمرة فبمجرد انتهاءه يبدأ من جديد. يلقى البحث الضوء على ارنباط هذه النظرية لنيششة بمفهوم التكر ار الالز امهى لاى فرويد وغيرها من أفكار ومفاهيم التحليل النفسى. يلقى البحث الضوء على "هكذا تحدث زارازاسثر ا" لنيشثة . بعثد البحث على بعض مفاهيم الثيوسوفية و الجسد الأثيرى و الاسقاط النجمى كوسيلة لخروج النفس عن الجسد فى جولة للبحث عن الذات وكذلك فكرة موت ما قبل الموت الحق. بطبق البحث هذه الأفكار على رواية موسم صبد الغزلان لأحمد مر اد الروائى المصرى المعاصر · يصور البحث هذه الأفكار الفلسفية و النفسية كذلك برواية موسم صبد الغزلان لأحمد مراد و كيف تعاملت 
الشخصيات معها وحالات خروجها عن الجسد المادى فى صورة جسد أثيرى يتجول بعوالم أخرى بحثا عن المعرفة التى بصعب الحصول عليها دون الخروج عن كينونته المادية. يطرح البحث سؤال ما إذا كان أحمد مراد بروايته يصدق على نظرية العود الأبدى لنيتشة وهل نجحت شخصيات الرواية فى اختراق حدودهم وطبيعتهم الانسانية وما إذا كانت الثخصيات أظهرت بالدليل القاطع قدرتهم مؤخر ا على فهم الذات و القضايا الوجودية الجدلية التى أثنار ها البحث. بات. 


\section{Introduction}

In an age where science and technology are thought to be partially subservient in blurring some of the edges of the divide separating human beings, man has continued to be greatly preoccupied with a further going beyond borders and further means of gaining knowledge. Therefore, the reconsideration of concepts of time and space, as conceptual existential borders, becomes the mania of contemporary philosophy. In line with the age's preoccupation, Nietzsche proposes his theory of eternal recurrence, a theory that suggests a removal or rather deconstruction of all types of time borders that hinder communication with others and impede the acquisition of knowledge especially self- knowledge. Nietzsche's philosophy, that seeks to fill the void in human knowledge, draws heavily on some theosophical concepts like incubation or astral projection and ethereal bodies. Science itself has been condemned by Nietzsche in favor of some irrational means of knowledge acquisition like dreams.

Speculating upon the enlightening role played by incubation, dreams or rather some meditative practices, in the acquisition of knowledge in Nietzsche's perspective, Rainer J. Hanshe proposes that knowledge is attained through reason as well as through other irrational areas of consciousness. Some contemplative practices like dreams and incubation are highly enlightening. Such irrational areas of consciousness witness the outset of an enigmatic irrational power. They have informative pictures and actions that help to explain actual life's perplexity and bewilderment (Hanshe 143). Therefore, Nietzsche suggests that "our literal and incubatory dreams are valid means for obtaining knowledge ... Through such modes, we gain a type of knowledge that incorporates both thinking and feeling, both the rational and the "irrational' aspects of existence" (Hanshe 143). 
Hanshe adds that Nietzsche's hypothesis is that dreams have a special supportive power that is not available elsewhere: the power of imagination that is at its height in the area of dreams. He believes wisdom to be gained through the working of imagination. Unlike rationality, imagination has an access to inaccessible areas of consciousness and knowledge; it crosses the borders and reaches spaces never seized by rationality. Thus, Nieztsche, as Hanshe concludes, believes that "In the dream or incubation state, the rational and the irrational intertwine, forcing us to recognize the thresholds of self-knowledge, that everything cannot be discerned through rationality alone "(142).

Presenting such enlightening concepts like the astral plane or the astral world where the individual can acquire spiritual knowledge, Morten Tolboll argues that wholeness takes three states of spiritual awakening. He further meditates upon the three states of the wholeness that are sleep, dream and awake as he writes:

The ordinary consciousness can sleep in three ways: 1) the dark sleep, which is the Ego's deep nightly sleep; 2) the grey sleep, which is the Ego's nightly dreams and other dreams; 3) the light sleep, where the Ego is awake. ... This structure is also called the astral plane, or the astral world. ... It is the world of the planetary spheres, crossed by the soul in its astral body, either through the dream state, or on the way to being born and after death, and generally said to be populated by angels, demons, spirits or other immaterial beings. (9-10)

Tolboll elaborates that in the spiritual existential plane, the astral plane, there is a type of records he ventures to call "Akashic records". They are records that contain a variety of spiritual knowledge including " all knowledge of human experience and the history of the cosmos. They are holding a record of all events, actions, thoughts and feelings that have ever occurred or will ever occur" (9-10). Furthermore, Tolboll elaborates that the 'Akasha' is an 'astral light' that carries obscure secret accounts recognized only by astral entities 
via their 'astral senses'. Such Akashic accounts facilitate the acquiring of some supernatural as well as spiritual talents like telepathy, spiritual intuition and foresight. This could significantly be done through practices like "astral projection, meditation, near-death experience, lucid dreaming, or other means" (10).

In line with Tolboll, reflecting upon the enigmatic realm of dreams, Peter Kingsley calls incubation " third type of consciousness" (Kingsley 31). According to Kingsley, incubation signifies a deathbefore- death meditative practice that involves journeying, for duration of hours or days, into the realm of the dead, an exercise that requires lying down insulated in a dim place fully tranquil and motionless. In other words, to incubate, one has to experience the state of 'hesychia' or rather tranquility (Hanshe 147). Thus, throughout the incubation process, one experiences a state of physical as well as mental quietude when everything is still and, as Nietzsche proposes, the shadow experiences of the psyche are released. To Nietzsche, "What we acquire in incubatory states is not what belongs to the social or herd nature, but to individual existence, the psyche's hidden depths, the "tiefe Himmel'" (Hanshe 145). In this stillness, equipped with a completely different consciousness akin to that possessed in dreams, one is allowed in another beyond space. The knowledge gained in such space is rather intuitive and spontaneous, acquired when journeying through imagination (Hanshe 143-44). Nietzsche argues that:

When incubating, one then moves beyond the surface and sign world, beyond the merely utilitarian into 'everything strange, unusual, and questionable,' what disturbs us because we do not know or understand it, or what we cannot access in waking life, due to the measure that we must observe in it, or to the demand to provide proof. (Hanshe 145)

Therefore, illuminating his speculations upon irrational means of knowledge acquisition, Nietzsche writes his highly 
comedic philosophical novel, Thus Spoke Zarathustra where Nietzsche calls upon a reevaluation of such illuminating intuitive items as "senses, intuition and the imagination" (Hanshe 142). In the novel, Zarathustra is significantly presented to the idea of eternal return of the same through his incubation experience wherein he receives wisdom and knowledge upon which his philosophy draws heavily (Hanshe 142). A further insight gained by Zarathustra is a belief in the power of images, parables and metaphors in the communication of his philosophical ideas (Hanshe 146). During his semi-conscious sleep state, incubation, Zarathustra experiences a distancing out of the soul described by him as he says, "My eyes he does not press closed; my soul he leaves awake. Light is he, verily! Feather-light. He persuades me, I know not how? He touches me inwardly with flattering hand, he compels me. Yes, he compels me that my soul might stretch herself out" (Nietzsche, Zarathustra 241). Nietzsche believes the distancing out of the soul to be an act of manipulating and disrupting time's authority when the past and the future are conveniently unfettered within the physical body in the present moment (Hanshe 145). This short-term-death, in Nietzsche's philosophical thought, should be repeated frequently over and over throughout one's course of life; it is only through such a repetition of the experience of death that immortality is made possible (Hanshe 148). Nietzsche calls upon humans to listen to the earth's whisper and to obey it because only then that one is able to "move beyond the egoistic subject and, in Nietzsche's terms, to think or feel cosmically, to overcome one' $\mathrm{s}$ worldly anthropomorphism and submit oneself to the earth - to obey it! It is to move into inorganic realms, to turn into a stone" (Hanshe 150).

Having suggested that the very process of knowledge acquisition is not merely a rational experience and that revelation and enlightenment could be the outcome of some irrational experiences, Nietzsche signifies his doctrine of eternal recurrence as an example of such knowledge that is irrationally gained. Beside Thus Spoke 
Zarathustra, the idea receives its clearest expression in The Gay Science where Nietzsche implicitly alludes to what he significantly calls irrational sources of enlightenment. In his book, Nietzsche's highly philosophical idea of eternal recurrence is hypothetically communicated by a demon. Nietzsche poses a stimulating provocative question that is bound to arouse the reader's interest and deep thinking. He asks about the way he would expectedly behave if he is struck with a demon who says to him:

This life as you now live it and have lived it you will have to live once again and innumerable times again; and there will be nothing new in it, but every pain and every joy and every thought and sigh and everything unspeakably small or great in your life must return to you, all in the same succession and sequence-even this spider and this moon- light between the trees, and even this moment and I myself. The eternal hourglass of existence is turned over again and again, and you with it, speck of dust!" (Gay Science 341)

According to the theory of eternal recurrence delineated by Nietzsche's demon, the world consists of a single series of events that are recurring infinitely many times. Because one's life is part of this series, one will live his life repeatedly many times. However, such belief in eternal recurrence stirs up issues concerning personal identity and time's metaphysics. Nevertheless, such hypothesis has been shockingly unsatisfying for Nietzsche himself who has always dreamt of "a decisive historical revolution, a time after which all would be different from the time before" (Nietzsche, Zarathustra $\mathrm{x}$ ).

However, to give it its full recognition, Nietzsche's theory of eternal recurrence has to be seen in light of an Eco philosopher's ecological philosophy and environmental ethics. Nietzsche's handling of nature and environmental ethics differs from that of standard postmodernism in some vital points. As Martin Drenthen argues, Nietzsche's philosophy is highly ecological; it builds heavily on mannature relationship. Man is an essential fragment of nature that can only come to a state of self- understanding in light of the ecological 
system as well as humans 'ecological bond with nature. Nietzsche's philosophy significantly opposes any“ 'metaphysical' explanations of ourselves as moral beings that presuppose a non-natural 'miraculous source' of morality. He explains all of the different aspects of human existence as symptoms of an underlying natural process" (Drenthen 5)

Nature, in Nietzsche's theory has a Dionysian power that endows Nature with certain commanding powers; it helps Nature to cyclically and freely resurrect creatures and takes out their lives while innately having neither wisdom nor ethics (Mask 14). According to Nietzsche's concept of Nature as having a Dionysian power, the individual's potency lies not in identifying himself as distinguished from Nature but rather in his belonging to it. This implies the necessity of the individual's complete surrender to Nature and to move beyond man-nature antagonism.

Describing such mutually antagonistic bond, Arthur Schopenhauer highlights the way Nature speaks about the individual as it says:

The individual is nothing and less than nothing. I destroy millions of individuals every day for sport and pastime; I abandon their fate to chance, to the most capricious and wanton of my children, who harasses them at his pleasure. Every day I produce millions of new individuals without any diminution of my productive power; just as little as the power of a mirror is exhausted by the number of the suns images that it casts one after another on the wall. The individual is nothing. (600)

Set against Nature's arrogance, Schopenhauer proposes the individual's too much narcissism and belief in himself. Each individual believes himself to be the center of the world and says to himself, "I alone am all in all; in my maintenance is everything involved; the rest may perish, it is really nothing" (Schopenhauer 
599). However, to righteously build his subjectivity, one has to put off all man-nature conflicts and to stop defying nature to allow eternal recurrence, as one of Nature's Dionysian powers, to enable the individual to build a "unified self" (Mask 104). In this respect, Mask argues that the individual should no longer think that he is powerful as long as he is able to rebel against or even to compete with Nature. $\mathrm{He}$ has rather to submit himself to Nature and to see his individual power, rather than his defeat, in those cruel natural facts like death and degeneration (77).

According to Mask, the individual's utter subjugation of himself to nature's totality of powers as well as his belief in such powers are two prerequisite of eternal recurrence. It is only then that one is brought back to life and is also allowed to be part of "the Dionysian power of Nature". In addition, this eternal recurrence philosophy is a chance for altering the individual's nihilistic feelings associated with death and mortality and proposing "a post-tragic view of the individual" (77).

In addition, though Nature fundamentally lacks peace, as it is marked by troubles and struggles, every troubling part of Nature is indispensable. Therefore, life is crucially hindered without Natural objects like "Death, suffering and decay" (Mask 14). Accordingly, Mask states, in Nietzschean terms, that opposite elements of nature could not be classified as superiors and inferiors in relation to each other. Nature should be a totality of contradictory elements that exist together where the exclusion of one element disturbs the ideology of Nature. Hence Nature's law of creation regards destruction as a prerequisite to life. On a similar ground, Nietzsche's philosophy of the opposite elements of Nature condemns Christianity's looking down upon sexuality regarding it as something evil, the thing that disintegrates life and nature's scheme (Mask 86-70).

In light of these philosophical speculations of Nietzsche's, Murad's Season of Gazelle Hunting (Mussem Seed Elgezlan) is a 
novel that starkly has a philosophical affinity to Nietzsche's thought. In line with Nietzsche, Murad highlights the significance of some irrational methods of knowledge acquisition, as set against reason. Such methods, as his novel implies, are dreams and incubation. In so doing, Murad skillfully parallels two lines of enlightenment and knowledge acquisition: the line of reason and that of other irrational practices that are equally enlightening. The novel therefore, parallels the cause of science with that of dreams and astral thinking. It also puts side by side physical and ethereal existence and fantastically marks the beginning of a new whimsical era in human history, one of going beyond borders and of interrelationship between previously unrelated antagonistic objects and realms. This shows everything in Season of Gazelle Hunting (Mussem Seed Elgezlan) as going beyond borders of reason, actuality, time, space, consciousness and unconsciousness.

Murad's depicted time marks a going beyond borders of actual time. The novel's time is much more concerned, as never before, with the realm of dreams and, therefore, with the flexible release and emancipation of one's fettered unconscious shadow experiences and hidden unconscious knowledge. However, this invasion of an irrational space is done with the aid of certain scientific inventions. Therefore, setting a suggested collaboration between rational and irrational methods of knowledge acquisition, Murad depicts science as a subservient aid for dream operating and management. In this respect, the novel starts with a lengthy dream that is modified by the protagonist's lens so as to be compressed in length from 51.1 seconds to 5.2 seconds to be watched by him (Murad 7). In this way, Nadeem, the novel's protagonist, can easily and flexibly move forward or backward through the recorded dream. He says, "I go backward in time for few seconds as I stop at the woman's face. I get it closer and examines it ... who are you?" (Murad 9).In addition, the "third eye" can, with the aid of an external lens like the glasses, catch up, records and adapts dreams and scenes to the actual time to be reloaded and 
watched at any time more than once. Nadeem describes the third eye's lens as follows:

It has the same characteristics of the traditional glasses yet it sticks to you as you sleep, as you make love and even as you swim. Just like you, it looks at anything and surrounds it with tangible data such as its manufacture date, efficiency and the way it works. It can help you manage your accounts and registers your day's occurrences, from your own point of view, with the highest degree of accuracy; it provides a chance for relaxation through color hypnotizing or stimulating sexual scenes; it pours music and movies into your senses, reads you biologically, analyzes your organs' efficiency in a detailed report and it records your dreams... (Murad 10)

A further suggested going- beyond- borders- experience in Murad's novel is significantly a going-beyond-borders of death through Nietzsche's suggested philosophy of eternal recurrence. From the very beginning, Murad prepares the reader to the deconstruction of the idea of man's mortality through the hypothesis of eternal recurrence. Repetition is the law governing everything. Everything is repeated over and over. Nadeem watches his dream over and over and Mariem reads Virginia Woolf's Lady Dalloway, for seventy times. Cloning has become the age's fashion, an idea that is suggested when Nadeem asks his wife Mariem, who is obsessed with the influence stars have over human life, if Madonna asks to be cloned just like Rihanna. Nadeem says:

-Did she ask to be cloned?

-No, she said it is enough for God to judge one Madonna.

-This is smart of her, Rihanna's replica is likely to die, just like her first copy, with drug overdose (Murad 13).

This idea of repetition as well as of eternal recurrence is linked to that of border removal. Murad proposes that after death, all borders are blurred between different living species so that a dead body's 
organic material goes back to nature and might, consequently, be resurrected in an animal, plant or even in a bird. In line with Nietzsche, Murad raises some existential questions that suggests the idea of the eternal recurrence in terms of borders removal. In this respect, Nadeem is asked by one of the audience:

What is after death? Where are those creatures that died millions of years ago? Where is Newton's apple? The answer is: nothing; death is the end of the journey. Like all types of energies, the energy we have inside does not come out of nothingness. It does not perish; we call itself or spirit. Anyway, regardless to its name, when the body's physical structure declines and falls down, this energy is gone and is distracted in nature among earth, animals and plants: recycling. (29)

Beside dreams as irrational sources of knowledge acquisition, astral projection is set by Murad as a spiritual illuminating practice through which the individual is bound to gain insight. This type of out- of- self enlightening journey is typical to Mariem's dreams. Describing the peculiar nature of her dreams and of herself as well, Nadeem suggests ethereal journeys, rather than ordinary hallucinating dreams, experienced by an ethereal transparent body where a sort of revelation occurs to her. He says,

Mariem is transparent; she is a highly receptive antenna. It happens that she dreams of a female neighbor, she has not seen for seven years, quarreling with her husband. She then, accidently comes across her to find her complaining and thinking of divorce. She might also see me in a dream that makes her stare at me all day along with tearful eyes or rather angrily presses on her teeth. She is also like sensors that habitually catch nothing but waves of sorrow and SOS signals (Mura 14).

Murad further removes barriers by delineating a peculiar world populated by people of extremely different natures living together involvedly. All Murad's characters do not belong in the world of 
actuality; they belong in two paralleled unfamiliar worlds that sound weird and bizarre: an ethereal world populated with ethereal bodies and a highly scientific and automated world, where everyone and everything is mechanical. However, there is no edge of divide between both worlds as they rather coexist together. This is highly suggestive as it reflects Murad's preoccupation with man's two sources of knowledge and the two types of consciousness: scientific and intuitive consciousness. To highly stress the scientific atmosphere of the novel, Murad makes the robot a major dominant character. Besides, man's body sounds like automated robots; everyone has a brain-disk that sends signals. In addition, airplanes are the habitual means of transportation. On the other hand, to reflect the novel's astral world, stars, holograms, planets, astral and celestial bodies are dominant figures.

Miscegenation is a further idea of borders removing of Murad's novel. However, in place of denoting a mix between races, it rather signifies a mix between physical beings and ethereal ones. It is miscegenation between the world of science and the astral world. Nadeem is Murad's representative of the realm of science; he is a man of science; his wife, Mariem, on the other hand, represents a ghostly ethereal being that floats in space among stars. Having once fallen down stairs and fainted, Mariem has consequently become absentminded as well as too much obsessed with astrology and astronomy; she takes no step forward without examining planets' angles and the moon's position (Murad 16). This suggests that Mariem exists almost exclusively on an ethereal level rather than a physical one. In Nadeem's words, “(s)he becomes absent-minded; a sort of heavy smoke has secretly entered her physical entity. She turns to be a ghost moving about all around the house, a ghost that says nothing." (Murad 16). Referring to the great gap between himself and Mariem, Nadeem describes himself as one "who has his cells regenerated with a rate of 125 million per minutes; he becomes a new person every seven years" (Murad 17). 
In line with Nietzsche, Murad's novel focuses on God's death wherein borders of religions and deities are dismantled. Following Neitzsche, a pioneer of the school of suspicion who criticizes fear and need as the two elements underlying religion (Davidson 32), Season of Gazelle Hunting (Mussem Seed Elgezlan) critically reflects upon religion and God. Man fears death and needs a hope for immortality. Nadeem says, “ in brief, man's dread of death is what creates the idea of God, a God who gives him a second chance for another new life after death, a paradise where he completes his short earthly life" (Murad 30). In addition, Murad could find a link between religion and the lust for power, an idea that figures prominently in Nietzsche's philosophic thought that suggests that what is behind religious commitment is the lust for power (Davidson 32). In this respect, giving the example of a robot's case and its macrocosm, Nadeem says:

As soon as its skin's outer layer is covered with nerve pain, laws of robot rights would be issued just as laws of human rights are available. Then, we put a system for its life in a book that frightens it of consequences and warns it of making mistakes. It lays rules of judgment including paradise and hell that burns its skeleton that is recombined there just to be burnt once again. And a bit by bit we envy it for its superiority and achievement. Then, we fight its existence and are obliged to put an end to it, a dead line as it is not destined to die. So we kill it with hurricanes, volcanoes and earthquakes. It resists and gets angry and when it realizes that we are not deities, it will triumph over us and when it accedes to the throne and starts to boast with its power and gets proud, it would think of creating a new species to be its worshiper and it is promoted to deserve the title God... (Murad 24)

Here Murad has skillfully and symbolically replicated the conditions of man's life in a robot's. As soon as a robot is manufactured, we play the role of god with it and lay our laws and restrictions that have to be followed and obeyed by the robot otherwise it would be fated with violent punishment and of being 
burned out in hell. Murad's protagonist, Nadeem, is then criticizing the idea of man's being manipulated with a deity and a constitution of spiritual strict laws devised by God. He also refers to the idea of death with all its cruelty calling it a deadline. He rather goes further suggesting that one day the robot itself would revolt against its god. However, gods never fall short of practicing their manipulation over their chosen species and would therefore look for further obedient automated or human individuals to widely practice their power.

The novel bears some resemblance to Zarathustra's case. Zarathustra believes that God is dead. He says "Dead are all gods: now we want the 'overman' to live" (59) Like Zarathustra's God, Nadeem's has died. Murad writes "God's crucified corpse will always remain an example for the coming God" (25).When Nadeem's daughter, Sulaf, died at the stadium of Berlin's Robot Olympics, as some of Dafa organization's prejudiced individuals have blasted a bomb there, Nadeem looked for any sign of God's existence yet found nothing. He has come to the conclusion that God died. Grieving over the death of God, he said: "God died. I cried as never before, as never cried over Sulaf's death nor my father's. Then, I gave up when I realized that, at this moment, I was absolutely liberated. I started to pray for myself, a horrible feeling, at first, that is much like riding a snaky train in kids' funfair" (Murad249). According to Nadeem, like God, the devil also died. In this respect, he said, "If you insist on the idea, the devil is a creature that lived and died like every living creature. He is a creature we oppressed, distorted and held responsible for our sins ..." (Murad 264).

In a sense, Nadeem seems to be Murad's parody or replica of Zarathustra and therefore, a suggestion of eternal recurrence. In other words, typical to Nietzsche's philosophical dogma, Zarathustra is fictionally cloned or is rather resurrected in Murad's Nadeem. However, this recurrence, with good or bad effects, is done with some differences. Zarathustra has submitted himself to a sort of voluntary 
exile for ten years in the mountains. There, he claims, he is liberated "from the view that the finite human world was an imperfect copy of something better, 'the work of a suffering and tortured god,", (Nietzsche, Zarathustra xxi). Murad's replicated Zarathustra, Nadeem, has gone into his voluntary exile according to a deal made with his friend Tarek. On a superficial level, Nadeem's submitting of himself to exile is meant to be the price for Shopan's original Piano, however, Nadeem's implicit target was Talia, Tarek's wife while Tarek's unspoken goal was revenge.

Nadeem's exile is “an old villa at Elzamalek, facing the valley of the dry river. It is lighted with candles and oil lamps rather than electricity. It has neither networks nor lenses and is utterly isolated. The place provides food, relaxation, quietness beside other spiritual services" (Murad 63). It is also a place of a technological atmosphere that has special apparatus that can cross all borders of time, space, conscious and unconscious as well as borders between humans and inanimate objects like robots. Individuals at this place are allowed to cross borders and can freely travel to a variety of places and ages.

Being a replica of Zarathustra, Nadeem is a scientist who delivers his lectures that are attentively attended by a large audience who never fails to ask him challenging inspiring questions. Like Zarathustra's, Nadeem's exile is a place where he experiences an outof-self journey or rather where he experiences astral projection and gains knowledge. However, Nadeem's repeated incubation experiences are enough enlightening and illuminating that they never fail, each time to equip him with a new piece of information once on the theological, spiritual and existential levels and another on a personal one. However, interestingly enough, all levels suggestively keep no edge of divide, where the personal suggests the theological and vice versa.

Nadeem's first out-of-self flight is a parody of the most critical scene in theological history when God asked angels to stoop for 
Adam. Nevertheless, the reluctant, rebellious and defiant devil who keeps inside a neurotic testimonial says, "I am superior to him as I have got an eye that possesses all sciences and I can fly with four wings. Besides, I am exceptionally skilled in hunting females. I will never stoop. You give me the power of choice and I have the right to say no, or I would not be able to say it right now, would I?" (Murad 104). However, this internal soliloquy that goes inside the devil is paralleled with his words to God declaring his going beyond His orders. Coming back of his ethereal journey, Nadeem is asked by Tarek about the issue of his coming lecture when Nadeem says "Devil" (107). Thus, in Nadeem's astral journey, the devil's issue is hypothetically revealed to him.

In his second astral projection journey, Nadeem watches a second dream where he, as a little child, like Adam, is introduced to forbidden knowledge: sexual knowledge. This occurs as he sees his parent in a very intimate sexual scene. The dream, then, sums up the repeated stereotypical example of man-woman relationship that strictly follows the law of eternal recurrence. It is a rather cyclic relationship that starts with sex and ends with a break up due to male unfaithfulness. The issue itself alludes to the devil's and Adam's issue where one is to be dismissed tell doom day and the other is doomed to leave paradise and go down to earth. Nadeem says:

At this night, father left packing his clothes in a bag. He brutally hugged me until I could feel pain and then, he departed. Mother said that he would travel somewhere and come back later to visit me weekly with presents and sweets. I asked my mother about the fate of my swing, her hand and father's that raises me up in air. I asked about the second brother they promised me just to give up the promise. (Murad117)

Nadeem's third astral journey is a speculation on a prospective dialogue between Gabriel and the devil that is cursed and doomed to live deprived of God's compassion and mercy till doom day. Gabriel 
asks the devil. "How did you dare to threat man and his descendants? To come to them from beneath and behind, right and left. How absurd!" (Murad 120). However, astonishingly, the devil hesitantly meditates between a desire to repent and a resolution to go ahead the way he goes; he expresses his regret and his desire to become once again an obedient servant of God's. He asks Gabriel“" If I ask for his forgiveness will he accept or is his forgiveness limited?" (Murad 121). Justifying his cause, the devil says that "one day human being will prevail on earth, killing God themselves" (Murad 122). He then asks "Where is Adam at the moment? On Elsafwa mountain? Enjoying the new throne he exerts no effort to get" (Murad 122). Nadeem, then, has got a nightmare wherein he unwillingly starts up a sexual intercourse with Mariem just to discover that he is rather having forbidden sex with his mother. The dream has its religious significance; the fact that he identifies Mariem with maternity sets Mariem as holy Marry.

In his fourth out-of-self journey, Nadeem speculates upon the issue of Adam and Eve. He sees the full account of the way Adam and Eve have been seduced by the devil. Eve seems to be pregnant carrying "the prospective prince of earth" (Murad 142-43). She is persistently enquiring about their fate and he keeps silent when the devil calls upon causing them to be scared and uneasy. Trying to lure them out of heaven by convincing them to approach the forbidden tree to eat one of its similarly forbidden fruits, the devil says:

The Devil. (Nadeem). How could he forbid you, the masters of earth, to approach this tree?

Adam. It was his only condition.

The Devil (Nadeem). How green and naïve you are. He forbids nothing but knowledge and immortality.

The female shouts.

Eve. You are a liar and I know not whydid not He killed you when you defied Him!

The Devil (Nadeem). A good question. To keep his pretended image of liberty and what proves my honesty is that if you eat the fruits of this tree you get the immortality he claims to possess, the 
immortality he exclusively grants Himself and consequently forbids you from. (Murad 145)

The devil further seduces them claiming that God lusts for supremacy, authority and power. Being infatuated with bloodshed, God would boldly allow them to be devoured. To seduce them more, the devil claims that, seeking immortality, He Himself has come to eat one of the tree's fruits. However, at this stage, Murad revises the issue of the forbidden tree highlighting that it was rather a fig tree rather than an apple one (Murad 146). Thus occurs the devil's first luring of man, and Adam has been condemned to live rather on earth. The tree's issue was nothing more than an obedience and loyalty test from God's part.

Highlighting the fact that Nadeem's dreams are nothing but astral flights, he himself describes his fifth out-of-self flight saying: “ the unconscious mind has gone into a coup against you, taking the ride from your hands and takes it upon himself to direct your boat in an endless cosmos ocean ... I starts to cite travel prayer" (Murad149). He sees Eve painfully delivering her first baby among trees and, therefore, convicts God for having merciless condemned woman to suffer an act of unbearably painful delivery. This leads him to ask a controversial question "Are females masochist by nature?" (Murad 150).

This fifth flight is obviously dedicated to the revision of the horrible image of the devil. However, it starts with contemplation upon man-woman relationship and the stereotypical life style imposed upon all females as representatives of Eve with one purpose in mind: showing that God is responsible for the oppression of woman. This is further highlighted by the obviously sarcastic statement: "Rumors say that women are masochist sin mode" (Murad 149). Eve, as well as all females, are fated to beget children and, consequently, decline. Adam, as man's representative, gives her up, out of boredom, and seeks other females in order to prevail and have his own descendants multiplied. The flight shows how previously existing races, The Ninedertal, have 
become extinct. The devil, then, seeks to dismantle the stereotypical brutal image of him propagated by the media and by God regarding it as a fake unfair image created to empower God and support his cause. Revising this horrific shocking image of a devilish creature who defies God, the devil lists the many ways he regretfully has once tried to atone for his sin with no sign of forgiveness from God. He says:

How could you ignorant believe me to dedicate my descendants to you so that they lure you to be doomed, to be dismissed from the kingdom and then to be burnt all in an everlastingly active volcano? How could you believe that I did not try to repent just to carry on a normal life? I sent appeals of forgiveness and pardons and I cried out, from upon the highest mountain, asking for compassion. I sat on the donkey's back, defaming myself, in a reversed order and I went about around the kingdom's walls to be thrown with rubbish. I hanged myself on a tree for a complete cycle of the sun then I cut off my wings sending them as a present. I have finally cut off my sexual organ to end up my line of descendants by myself.... (Murad152)

Furthermore, the devil admits that he did nothing after being dismissed by God and that he became, instead, an anonymous being among all creatures, helplessly waiting for death to come as he is condemned to live till doom day. He believes God to have obliterated his issue and to have written history his own way to turn the devil into a terrifying myth (153). Then, to further cast doubts on God's issue of the devil, he poses some crucial questions: "What if I have stooped? Would the world be with no devil? Did he know before that I would refuse to stoop? Why then did not he prevent me? Did he desire to create a villain to push people forcefully towards evil and then to be condemned for their sins?" (Murad 154). He then poses a more important question concerning Adam and Eve's fate if the devil complied and stooped. God himself has previously said that he is sending man to earth. However, he has to live constantly in fear and struggle in order not to revolt against Him (Murad 154). Applying the stick and carrot policy, God promised man seventy two females in 
paradise against which is set a series of tormenting plans devised for sinners (Murad 154-55).

The devil has finally turned into pieces the persistent stereotypical image bestowed upon him as he describes himself in the following manner:

I am an aging man being created of a vibration other than yours. I am two thousands and seven hundred years old. I was dismissed out of God's kingdom and casted out with no trial. I witnessed Adam and Eve's death and I witnessed the descendants struggling over the vast lands and, without being involved, the one killed his brother and the murdered's son took it upon himself to take revenge... and now I am neglected in the paradise of illusion beside the so called immortality tree. (Murad 155)

Murad proposes the idea that human beings have supported as well as propagated the concept of the devil to justly cast themselves guiltless since only the devil is responsible for luring them. Murad writes, "The creation of the devil helps human beings to relieve their conscience of guilt complex" (Murad 262). For the image to be further completed, they, according to Murad created the image of a violent tyrannical God (263).

The following and last stage of his astral journeys is a highly developed one that is completely different from the ones that preceded .This stage, as Murad called it, is the "Theta stage" wherein Tarek inserts a needle between Nadeem's eyebrows that, supposedly, closes up an energy passage in the brain's center of lies forming (Murad 177). It is a stage of "Past life Regression Hypnosis", a technique of restoring back one's previous life according to the concept of the soul's resurrection in another body to live another life (Murad 175). In such a stage, Nadeem's "Hippocampus", a place where all dreams, memories as well as previous lives are stored, is opened (Murad 205). The technical sets would read the waves produced by the memory's center handle and condense them in a box (Murad 178). This is the 
phase wherein Nadeem is introduced to Nietzsche's idea of eternal recurrence. Following Tarek's instructions, Nadeem started to see different replications of himself in different times and ages. He first saw one who seemed to be his own replica but in another time. The man's name is Sirgious, a helpless Roman Christian craftsman, in seemingly ancient times, who manufactures swords. He has a wife and loves her but, for one reason or another, is not happy with. Nadeem believes Sirgious to suffer from a sexual disease that never gives him a peaceful death as he lives to atone for the sins of all creatures since they all have been nothing but fish in seas (Murad 190). Asking Tarek about what he sees, Tarek says, "this is one of your replications and do not feel shocked to see yourself once a female" (Murad 189).

The second replication of Nadeem is Gaber, a Muslim magician in Egypt, who performs a horrible show with a serpent. He has a sexual affair with a princess who becomes pregnant and her guard kills him, as a result, by forcefully giving him a knock on his head. To his astonishment, Nadeem himself has been born with a scar in his head at the same place. There follows the third replication of Nadeem who is, Zakhary, a Jewish clergyman and a jewelry shop owner of about sixty who is married to a very fat woman just like him. He has got a son from his ex-wife who hates his father. Zakhary wrote a very odd will; he ordered that his son should never inherit his possession until his mother dies. He, thus, should wish his mother to die. Zakhary died finally when his son hit him forcefully with a seven-candle lamp exactly in the same place of the scar Nadeem has got.

Having finished his astral journey through the past, Nadeem asks himself, "Who are those whom I met? Sirgious, Gaber and Zakhary? The smith man, the magician and the Jewish clergyman! Why did their images and details seem clear and three dimensional as if I have lived their lives one day?" (Murad 209).However, Nadeem is told by Tarek that he has seen just three replications of him out of thousand (206). Murad has significantly presented the three past 
replications of Nadeem as belonging to three different religions, whereas Nadeem himself does not believe in God. This is to refer to the idea that eternal recurrence of the same does not mean a copying of a model but rather a repetition with a difference. At the end of the Theta stage, they open the box to examine the condensed memories and they have astonishingly found the ring of the fat Jewish clergyman. Collecting information, through his lens, Nadeem visits the Jewish temple in Egypt, examines ancient files where Jewish clergymen's names are registered together with their photos. $\mathrm{He}$ makes sure that Zakhary was one of them and found him identical in shape to the one he saw in the "Theta" stage. In addition, he sees the ring's picture; it is identical to the one he has got. Nadeem then, asks himself, "Did I live on earth before? A new life starts just to end and then starts to end! -------!" (Murad 221).

Nadeem has finally summed up the idea that knowledge is acquired through different irrational means like dreams; he significantly highlights self-knowledge as the main interest of studying the phenomena of eternal recurrence. Tarek says:

Tarek. The goal of the resort is to reach a state of selfknowledge that is to say the truth of your thinking, the origin of your habits that comes from your past cloning, the past that affects you and make you Nadeem. This is not your first time on earth and I think you start to notice the model. The model!

\section{Nadeem. Model!}

Tarek. Sure, the female has had a great influence in the three lives you have lived (Murad 274).

Tarek, then, convinces Nadeem, who is not satisfied with the hallucinations and visions that visit him from time to time, that Nadeem has to close a door he has opened to his past. This could only be done by going through the last stage of the experiment which is roughly called "life between lives" (Murad 275). This denotes his last replication before the present one. Tarek claims that being acquainted with one's last presence close the circle of hallucination and one 
finally reaches answers, the thing which does not normally occur to everyone (Murad 275).

Explaining further why one is not normally aware of his past replications or lives, Tarek proposes that this is due to a substance responsible for blocking memories in the cells of "Hippocampus" and seeks to make one forget his past lives. However, any disturbance in such a substance causes a release of some memories in dreams so that one gets up astonished to have visited a specific time or place he has never been to (Murad 279). Nevertheless, the risk of the "life between lives" stage lies in the failure to re-block memories once again so that keeping the borders between the past and the present life becomes nearly impossible (Murad280). A further risk in the experiment is that Nadeem has to temporarily die and his heart has to stop for a minute. Having committed himself to the stage's conditions, Nadeem sees his last replication as a famous pianist, Yusuf Marawan, who paid every penny to buy Shopan's piano and he sees Tarek setting beside his fiancée Laila, a dark-haired pretty girl. Yusuf suddenly threw a flower to Tarek's female companion. Being seduced by Nadeem, Laila left Tarek and got married to Yusuf who betrayed her with Talia, one of his admirers. Laila committed suicide putting some stones in a coat's pocket and drowned herself in the sea. However, she left a note to Tarek that says "I will never forgive myself for what I have done to you" (Murad 323). Nadeem's replication, as a result, committed suicide by shooting himself where his scar lies. However, before committing suicide he asked himself " who am I? I am the devil" (Murad 303).

Nadeem then comes back to life in an experience that looks like a baby's delivery out of his mother's womb. He is astonished to find Laila's necklace that he saw in his last astral flight, in his hand. However, what is more astonishing is that he sees Mariem beside out of conscious; she has seen everything Nadeem experiences. He, then reasons that Laila is nothing but Mariem's replication who died just 
like Virginia Woolf, the author of "Lady Dalloway" a novel that Mariem keeps on reading repeatedly. Mariem reasons, then, that she and Nadeem have met before in another life and that the everlasting pain in her chest is due to the fact that she has herself once drowned in a previous life. Tarek told Nadeem the rest of the story when Nadeem has locked himself in this same house and room where he drew a face half Mariem/ Laila and half a fish. He consequently shot himself dead, however, his unrest soul kept on wandering tormented in the house. Laila kept on visiting Tarek's dreams and has once asked him to contact Hady, Yousuf's young-guy servant. Hady has been known to be by nature a spiritual mediator. He could never find an explanation for the smoke he could see in the house's corners nor for the sounds could he hear. He saw Yusuf's soul wandering abouton his suicide day, a tormented blind crying soul that could not believe it died and that kept on visiting Tarek's dreams. Hady told Tarek the whole story and the later bought the villa with Yusuf's stuffs of clothes and ornaments plus the piano. Tarek could, with Hady's help, come to contact with Yusuf; he convinced him that he committed suicide and when he stopped to appear in the villa, Tarek reasoned that he is resurrected in another body. Tarek told Nadeem that Talia is nothing but a robot; he makes her excitingly attractive to Nadeem who replicates the old story since man, as Tarek puts it "in his second coming chooses to correct the faults in his previous life, he chooses his father and mother and unfortunately, he often chooses one of his admirers to steal her from her lover in the same way" (Murad 328)

Thus, Nadeem's astral journeys, as proposed by Nietzsche, help him to gain knowledge and wisdom on the existential, theological and the personal levels. On the existential level, Nadeem is introduced to the idea of the eternal return of the same and the fact that after one's death, his soul is resurrected to live in another body a second life. On the theological level, he has come to the idea that doubt is the utmost degree of belief as it is through doubt that one comes to a state of belief (Murad332). Nadeem therefore, deals hermeneutically with a 
variety of religious issues including Adam and Eve's story and the devil's issue. On the personal level, Nadeem discovers that he himself is the replication of the devil, an idea that is made clear in identifying himself with the narrator (the devil) of Adam's issue in the dream as the narrator uses the first person singular "I". This is highly suggested after Nadeem's fourth astral experience as he removes all lines of the divide between the dream's narrator, the devil, and himself. He says, "I'll be around if you need something from me and you will. Days are enough vigilant to reveal the true friend. I said the words and looked at the sky without discerning is it morning or night ... ahead to me a hot dish of herbs with Talia setting behind" (Murad 147-48). Another type of personal knowledge is revealed to him as Tarek explains that Nadeem suffers "a Madonna whore complex" that makes him unable to approach Mariem sexually (Murad 320). Tarek himself symbolizes the revengeful God, Nadeem described, who has been lurking to revenge from Nadeem. Nadeem has once said, "One day I have collaborated with the scientists to climb God's wall to burn his ancient house but he has come to take revenge" (Murad 318).

A further type of knowledge Nadeem acquired through his incubation experience is that there is a store of past lives and a certain chemistry that blocks memories (279). Nadeem has seen three past replications of him to which the last replication is added in the "life between lives" stage where he saw himself as a famous pianist. However, the most important replication of all is that of the devil. In his second incubation experience, Zarathustra is bitten in his neck by a serpent that helps him to awake in time ( Neitzsche, Zarathustra 50). The serpent evokes to mind the idea of forbidden knowledge as it was the serpent that seduced him to eat from the forbidden tree. Like Zarathustra, Nadeem has been bitten in his neck by a serpent (Murad 270)

Following Nietzsche's ecological philosophy, Murad's novel reflects the process of self- understanding as depending on an 
understanding of nature and man-nature relationship. The title of the novel itself significantly alludes to man-nature identification; it identifies woman with one of the natural resources, an animal, namely the gazelle, since gazelle hunting obviously means luring and ensnaring women into a sexual relationship. Besides, the word season itself is highly natural as it signifies nature's four seasons; it further denotes a close bond with Nature. In addition, Nietzsche's proposition that the Dionysian power of Nature makes eternal recurrence possible is highly suggested in the fact that Nadeem is frequently served a dish of herbs to help him to start his ethereal flight where he gains insight in eternal recurrence.

Murad depicts a fundamentally altered Nature that matches the ultimate changes in man's self. This is identified by Murad as he refers to the earth's being supposed to a Mediterranean earthquake that drowns Alex. Murad has skillfully built a stark relationship between this ecological occurrence and Nadeem's self-discovery or understanding of an original figure of the famous pianisthe, as Nadeem, is replicating. Here, Nadeem/the famous pianist, as a human resource of Nature, is identified with an oppressive natural resource, the earthquake whereas Tarek identifies with the oppressed part of Nature, Alex that is drowned. In "Ecological Feminist Philosophies", Karen J Warren divides dominated objects into 'human others 'and 'earth others'. The first group refers to minority groups like women, the Blacks or any other prejudiced section of society while the second one suggests ill-used natural objects like trees, streams, animals, forests, etc (1).

Thus, a natural resource (the earthquake) oppressed another just as a human resource (the famous pianist) destroyed another. In Ecological terms, this suggests that when Nature is objectifies, man is similarly objectified. In another situation, Laila's troubled self is identified with the Nile River; both seem to be weak, pale and hesitant. Murad writes, "the Nile still streams in the valley, feeble, 
withdrawing from the side banks. Water's pre- death struggle starts to grow. The wedding ring is still in Laila's finger. A little bit large, Laila kept on removing and putting back the ring in place in tension (Murad 294). Furthermore, in another reference to a man-nature inevitable bond, Tarek is compared to apenguin (Murad 296). This might suggests that the theory of eternal recurrence dissociates the link between all human and natural resources; this entails that the cyclic return of man might be in a natural object or in the form of an animal.

Besides, Murad highlights a close relationship between the solar cosmological system, as part of Nature, and human beings 'psychic mode and fate. Hence, the appearance and movement of comets as well as the state of the moon have their connotations. For example, when the moon is full, Laila's relationship with the famous pianist and her forsaking of Tarek are completed (Murad 297). Besides, at sunset time, as the comet is fading away, Laila filled her pockets with pebbles and went into the sea committing suicide in Virginia Woolf's style. Like the comet, she faded away (301-2).

Though Murad's artistic goal is to present Nietzsche's philosophy of the significance of man-nature reunification, that's a source of the individual's power, he rather highlights the fact that man has gone astray by over-identifying himself with an extraordinarily developed science and technology. In so doing, Murad gives Season of Gazelle Hunting, (Mussem Seed Elgezlan) a special scientific atmosphere that significantly distances the novel's time ahead for hundreds of years in the future. The novel is, thus, a scientific fantasy that has a very specific unfamiliar vocab which skillfully reflects an age where individuals are too much obsessed with science and scientific inventions. Murad's characters have something automotive about themselves; they seem to be electronic devices that are more mechanical than human. Their physical and body building is described in a manner that habitually illustrates different functional organs other 
than ordinary ones; this sets them as super humans who are physically and substantially developed with the passage of time. This is made clear in highlighting significant hidden imperceptible body spots like the "third eye". However, this obsession with rationality goes hand in hand with an obsession with other irrational realms.

This obsession with science sets man as completely detached from Nature and natural resources and as even hostile to Nature. All the characters in his novel follows science's claim rather than Nature's the fact that shows them as hesitant and failed incomplete individuals. Even their senses' power has been destabilized and replaced by automotive senses or technological sets. This hinders their gaining knowledge through the irrational methods identified by Nietzsche. Moreover, man prefers science to Nature the fact that is made clear in Nadeem's sexual obsession with Talia, a robot that is set in sharp contrast with his sexual withdraw from Mariem. Thus, rather than identifying with Nature, Murad's characters are in conflict with Nature seeking through ages to subjugate it by science. However, against those characters is set the character of Hady who seems to have got wisdom through the supernatural skills bestowed upon him. This idea has skillfully been suggested by Murad as he highlights Hady's nudity. This nudity is meant to show him as completely identifying with nature and as rejecting anything that distorts his natural stance even if it is clothes.

Just as Murad has depicted man as resentful of Nature, he has, in response, shown Nature in rage and fury; this is depicted in the manifestation of its most destructive natural forces, the Mediterranean earthquake. It, thus, is revengeful and shuns her war against man. In addition, through Nadeem's repeated astral travels that are regarded as repeated temporal death, Murad seeks to help man to come to terms with one of nature's elements, death. 
The paper argues that Murad's Season of Gazelle Hunting, (Mussem Seed Elgezlan) is typically following Nietzsche's line of philosophical thought including Nietzsche's hypothesis of the irrational source of knowledge acquisition like dreams and astral projection. In Murad's novel, the knowledge acquired through such irrational means includes the notion of the eternal return of the same beside some theological suggestive ideas regarding the concept of the devil.

Like Nietzsche, Murad suggests the death of God and likewise, refuses the metaphysical idea of morality that derives a lot from the concept of the devil's seducing of man and leading him astray. This is why he casts doubts on the devil's image propagated by God. Murad's idea, then is that man's morality is to be understood naturally rather than metaphysically. Therefore, following Nietzsche, he proposes an ecological theory that manipulates human beings and helps them to come to a state of self-understanding and illumination. Murad, then is supportive to the idea of the significance of the individual's submission to Nature. This is bound to make him part of the Dionysian power of Nature that makes possible the eternal recurrence as well as taking out the lives of creatures. However, Murad highlights the individuals' failure to belong in Nature. He rather depicts an antagonistic bond between the individual and Nature showing the former's seeking to triumph over Nature by science and the latter's response in fury and anger. Murad, therefore, highlights science as a hindrance that sets man back in his proceeding towards Nature and he sacrifices everything like God and science for the sake of Nature. 


\section{Notes}

"رجعت بالزمن لحظات للوراء حتى توققت عند وجه السيدة، قربته وتمعنت فيه... من أنت؟؟"(مر اد 9 ).

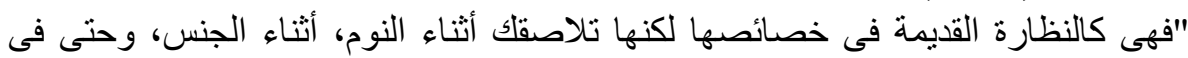

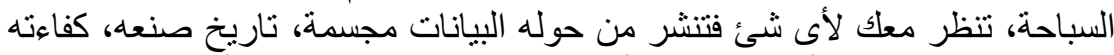

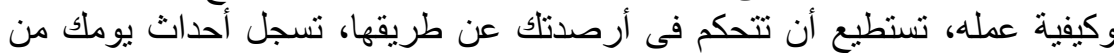

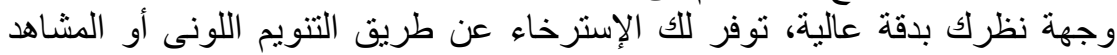

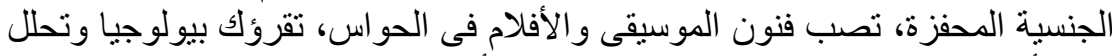
كفاءة أعضائك بتقرير مفصل، بالإضافة لتسجيل أحلامك" (مر اد (). "طلبت بستنسخو ها؟

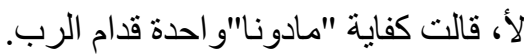

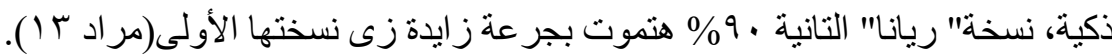

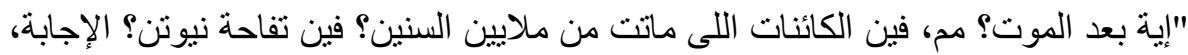

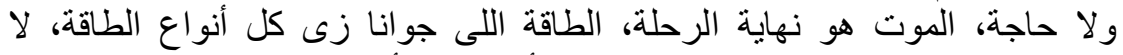

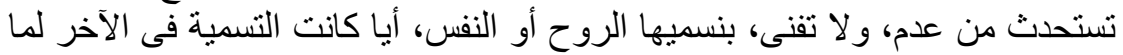

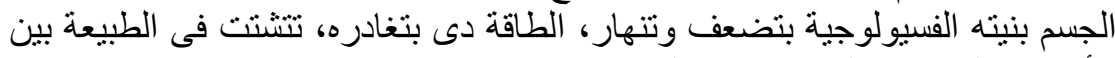

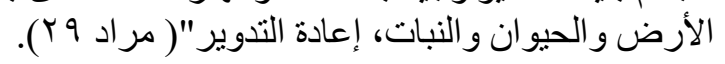

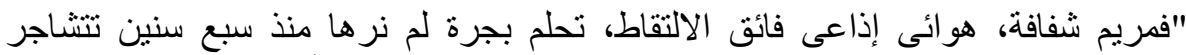

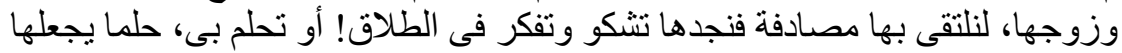

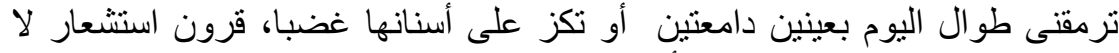

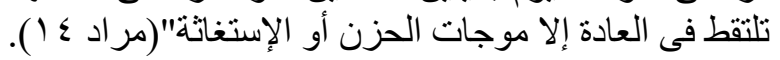

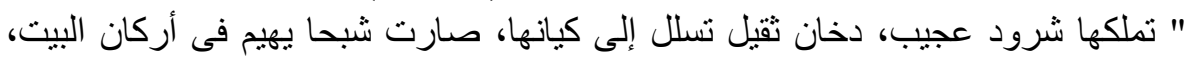

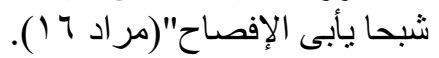

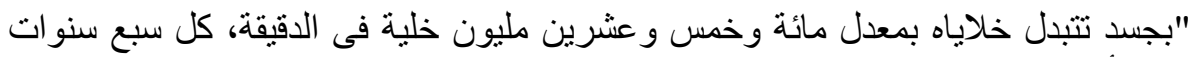

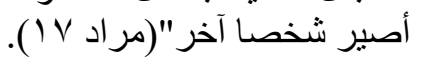

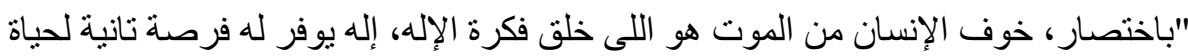

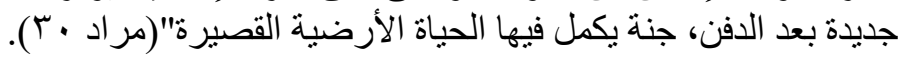

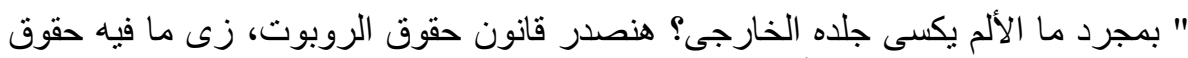

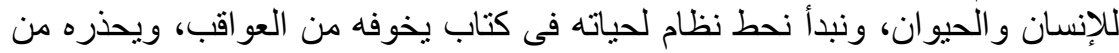

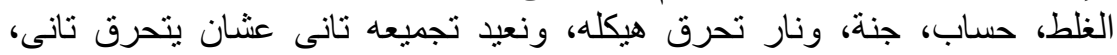

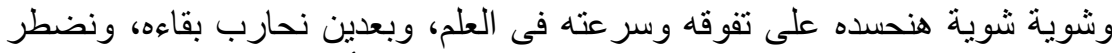

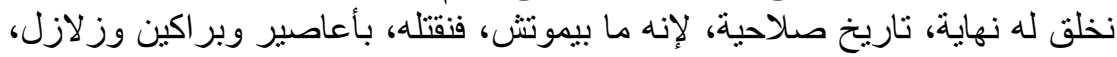




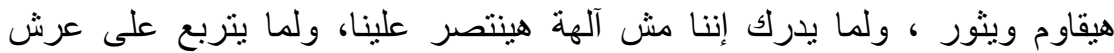

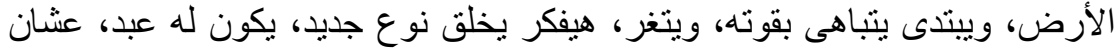

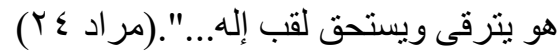

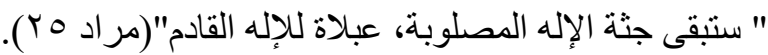

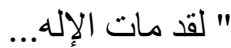
بكيت كما لم أبك من قبل.....

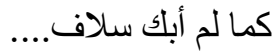
كما لم أبك أبى..... ثم توقفت حين أدركت أننى فى تلك اللحظة قد تحررت تماما... أصبحت أصلى لنفسى..

شعور مخيف فى بدليته، أشبه بركوب قطار ثعبانى فى ملاهى أطفال".(مر اد 9 ؟ ؟)

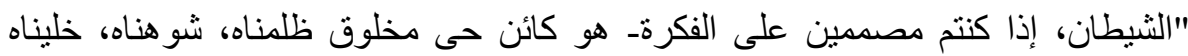
المسئول الأول عنز خطايانا، أعتقد جه الوقت نفهم إن الثيطان الحقيقى ببساطة هو

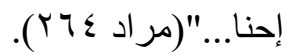

" فيلا قديمة بالزمالك تطل على و ادى النهر الجاف، تضاء بالثموع و والقناديل، لا الكهرباء،

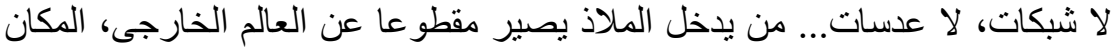

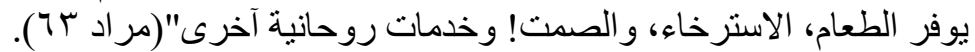

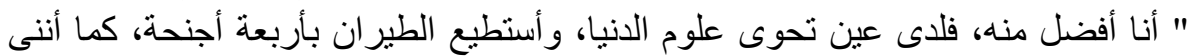

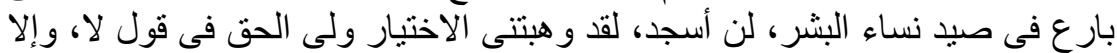

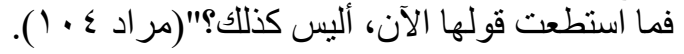

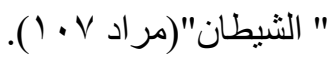

" فى تلك الليلة غادر أبى البيت، وضع ملابسه فى حقيبة و احتضننى حتى آلمنى، ثم رحل.

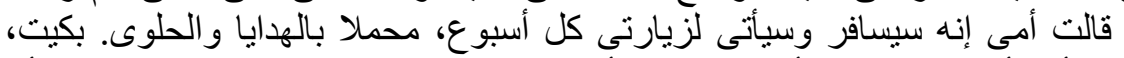

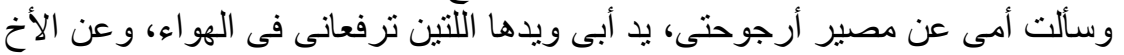

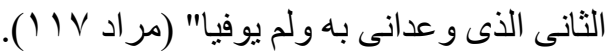

" كيف سولت للك نفسك تحديه أمام الملأ؟ وكيف تهدد البشرى وذريته؟ تأتيهم من بين أيديهم

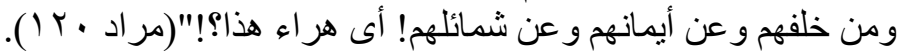

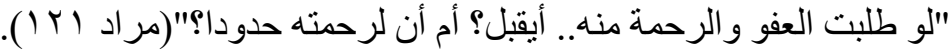
" سيصير البشر أسياد هذا الكوكب، وسيقتلون الإلة بأيديهم يوما"(مر اد ب r I ).

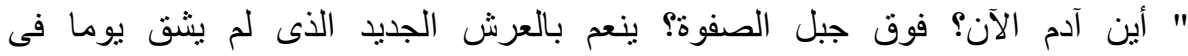

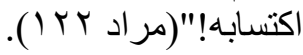

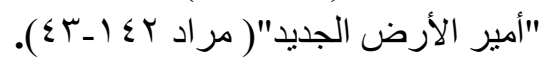

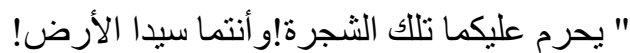


- يالكما من غشيمين ساذجين، لم ينهكما إلا عن المعرفة و الخلود.

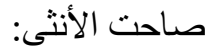

ـأنت كاذب، و لا أعلم لم لم يقتلك حين تحديتها

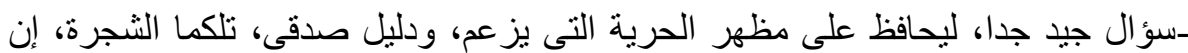

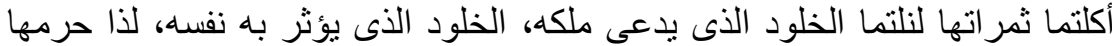

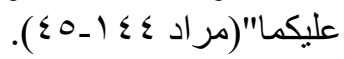

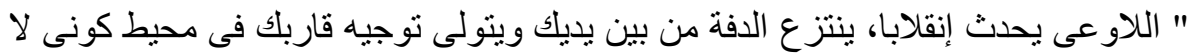

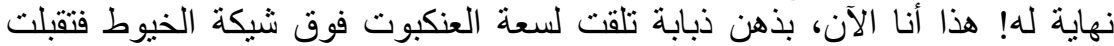

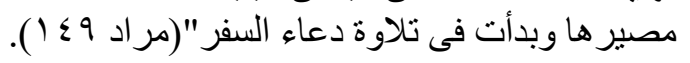

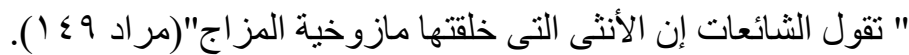

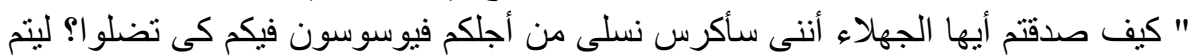

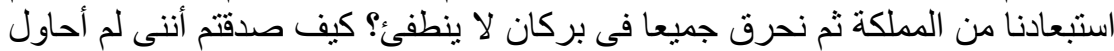

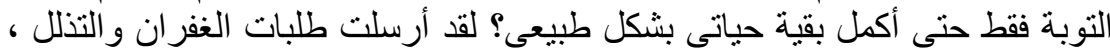

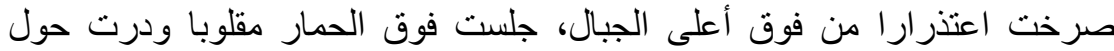

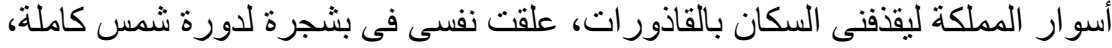

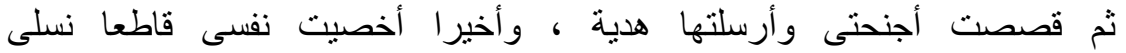

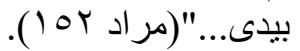

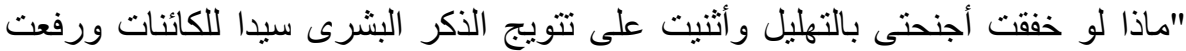
لافتة عليها قلب أحمر كبير هل سيصبح العالم بلان شيطان؟

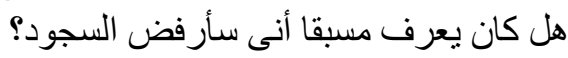

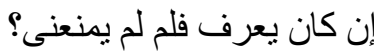

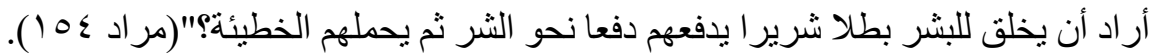

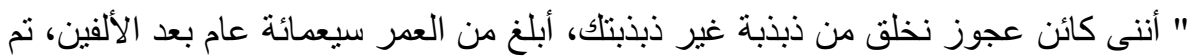

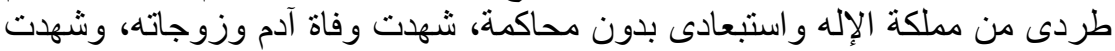

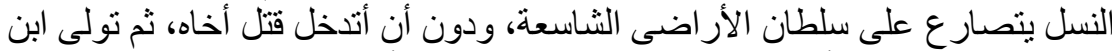

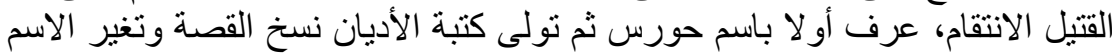

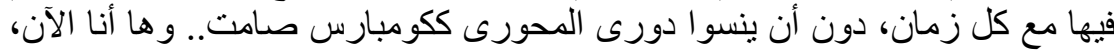

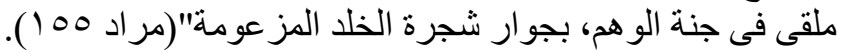

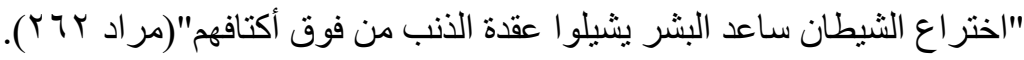

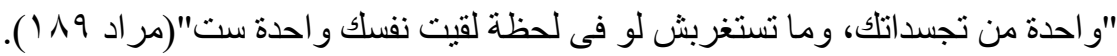

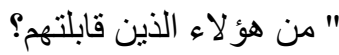

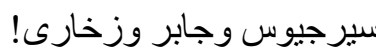

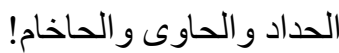
لم بدت صور هم وتفاصيل حياتهم واضحة ثناثثية الأبعاد كأنى عشت حياتهم يوما؟"(مر اد . ( $(Y \cdot 9$ " هل عشت على تلك الأرض من قبل؟ 
حياة جديدة تبدأ لتنتهى، ثم تبدأ لتنتهى!"(مر اد ا (Y).

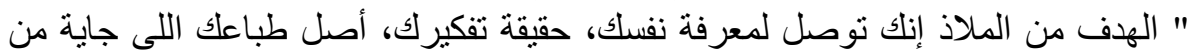

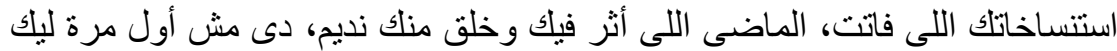
على الأرض، وأعتقد إنلك بدأت تلاحظ التى النمط. -نمط! ـطبعا، التلات حيو ات اللى عثتهم قبل كدة، الأنثى كان لها تأثير كبير فيها"(مر اد ع ؟ Y).

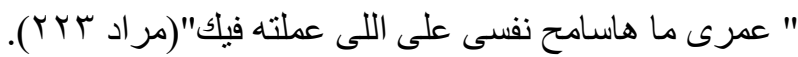
" من أنا؟

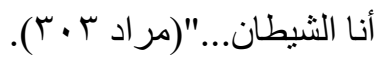
"إن الإنسان فى العودة للعالم تانى، بيختار يصلح حياته اللى فاتت، بيختار أبوه و أمه،

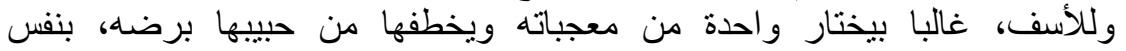

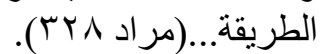

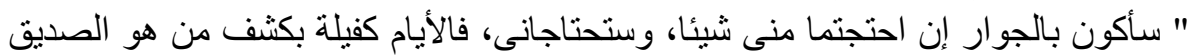

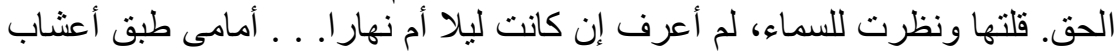

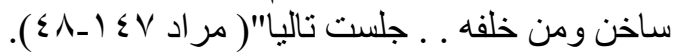
" لقد شاركت العلماء يوما فى تسلق سور الإله وحرق بيته العتيق، لكنه عاد لينتقم"(مراد (r) 1 (

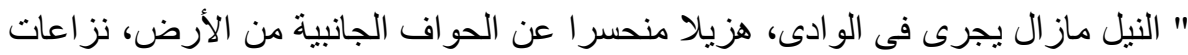

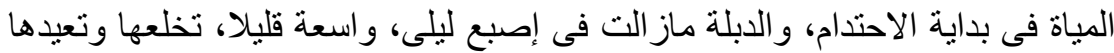

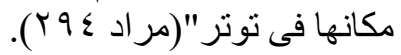




\section{Works Cited}

Cybulska, Eva. "Nietzsche's Eternal Return: Unriddling the Vision, A Psychodynamic Approach." Indo-Pacific Journal of Phenomenology, vol. 13, no. 1, 2013, pp. 1-13., doi:10.2989/ipjp.2013.13.1.2.1168.

Davidson, Scott ,ed. "Ricoeur across the Disciplines" .The Continuum International P G, London ,2010, pp.30-43. https://www2.bc.edu/ kearneyr/pdf_articles/p186244.pdf

Drenthen, Martin. "Nietzsche and the Paradox of Environmental Ethics." New Nietzsche Studies, vol. 5, no. 1, 2002, pp. 12-25., doi:10.5840/newnietzsche200251/22.

Hanshe, Rainer J ."Zarathustra's Stillness : Dreaming and the Art of Incubation." Nietzsches Therapeutic Teaching, pp.141-155, doi:10.5040/9781472548115.ch-011.

Kingsley, Peter. Reality .California: Golden Sufi Center, 2003.

Mask , Kyle Evan Mask. Eternal Recurrence and Nature.2008. Texas A\&M University. Dissertation.

Mask, Kyle Evan. "Eternal Recurrence and Nature.” 2008.

Murad, Ahmed. Season of Gazelle Hunting "Mussem Said Elgozlan", Cairo, Elshrouk Pub, 2018.

Nietzsche, Friedrich . The Gay Science . Edited by Bernard Williams, Translated by Josefine Nauckhoff. Cambridge, Cambridge UP, 2001.

. Thus Spoke Zarathustra: A Book for All and None. Translated and Edited by Adrian Del Caro, Cambridge, Cambridge UP, 2006.

Pearson, Keith Ansell, editor. A Companion to Nietzsche, Blackwell, 2006. 
Dr.

Rowe, David. "The Eternal Return of the Same: Nietzsche 's 'Value-Free' Revaluation of All Values". Parrhesia,15, 2012, pp. 71-86.

Schopenhauer, Arthur. The World as Will and Representation, Translated by E.F.J. Payne. New York, Dover Publications, 1969.

Schopenhauer, Arthur, et al. The World as Will and Representation. Cambridge, Cambridge UP, 2018. 